\title{
Comparison of propranolol and Ro 3-3528 in hyperthyroid tachycardia and dysrhythmias
}

\author{
EILEEN M. PHILliPS \\ B.Sc., M.R.C.P.
}

\author{
Paul Turner \\ M.D., B.Sc., M.R.C.P.
}

\section{JOAN HOUGHTON}

Department of Clinical Pharmacology, St Bartholomew's Hospital, London E.C.1

\author{
D. G. FERRIMAN \\ D.M., F.R.C.P.
}

North Middlesex Hospital, Silver Street, London N.18

\begin{abstract}
Summary
Ro 3-3528, a non-selective $\beta$-adrenoceptor blocking drug which lacks intrinsic activity, produces a doseresponse effect in hyperthyroid tachycardia, and shows no dysrhythmic properties. In hyperthyroid patients, $\beta$-blocking drugs of this nature are preferable to those possessing intrinsic sympathomimetic activity, which may have dysrhythmic properties in this condition.
\end{abstract}

\section{Introduction}

Ro $3-3528$ is a nonselective competitive $\beta$-adrenoceptor blocker, which, in normal volunteers, is five to six times more potent than propranolol given intravenously (Haefely, Hürlimann \& Thoenen, 1967; Hicks \& Phillips, 1972). It is known to lack intrinsic sympathomimetic activity in reserpinized rats (Parkes \& Parks, personal communication).

The hyperthyroid state is associated with enhanced responses to exogenous catecholamines (Schneckloth, Kurland \& Freedberg, 1953), while adrenergicneurone-blocking drugs may diminish the peripheral manifestations of hyperthyroidism (Canary et al., 1957: Goldstein \& Killip, 1965). Wilson, Theilen \& Fletcher (1964) found that the $\beta$-adrenoceptorblocking drug pronethalol failed to reduce the peripheral cardiovascular signs of spontaneous and experimental hyperthyroidism, and this drug has marked intrinsic sympathomimetic activity (Black, Duncan \& Shanks, 1965). In contrast, a doseresponse inhibitory effect on hyperthyroid tachycardia was shown for propranolol, a compound which has no significant intrinsic activity before metabolism (Turner \& Hill, 1968). Studies on other $\beta$-adrenoceptor-blocking agents in this condition have since shown that those drugs possessing intrinsic activity fail to produce dose-response inhibitory effects (alprenolol, oxprenolol, practolol, prinodolol) whereas sotalol, lacking in intrinsic activity, does so (Turner \& Hill, 1968; Turner, 1970; Ekue, Lowe \&
Shanks, 1970; Arbab \& Turner, 1971). Moreover, dysrhythmias may occur following drugs possessing intrinsic activity, presumably due to the enhanced responsiveness to agonist activity in the hyperthyroid state (Turner \& Hill, 1968).

The present paper compares the inhibitory effect on hyperthyroid tachycardia of propranolol and Ro 3-3528 in two comparable intravenous doses with that of a saline placebo, observes the incidence of spontaneous ectopic arrhythmias before and after injection and measures the plasma levels of both drugs obtained after injection.

\section{Subjects}

Six patients of proven hyperthyroid status were studied prior to treatment. Two men and four women aged 26-58 were admitted to either $\mathrm{St}$ Bartholomew's Hospital or to the North Middlesex Hospital for 5 days. All were free from cardiac disease, bronchial asthma, hepatic and renal disease, and from diabetes mellitus. Full blood count, blood urea and electrolytes, serum proteins, alkaline phosphatase, and serum glutamic oxaloacetic transaminase and hydroxybutyric dehydrogenase were normal. Urinalysis was normal. Electrocardiographs were normal apart from the presence of spontaneous supraventricular or ventricular ectopic beats in five patients. Informed consent was obtained from each patient.

\section{Procedure}

At 24-hr intervals patients received saline placebo, low or high doses of propranolol, or comparable doses of Ro 3-3528 intravenously under doubleblind conditions (Table 1). The order of treatments was random, but low doses were planned to be given before high doses. In spite of this precaution, two patients showed such a drop in heart rate during days $1-3$ (of the order of $20 / \mathrm{min}$ for subject BP and 
TABLE 1. Plasma levels of propranolol and Ro 3-3528 obtained at 10 min after intravenous injection in low and high doses in six hyperthyroid patients, and incidence of spontaneous ectopic beats observed for 5 min before and $17 \cdot 5 \mathrm{~min}$ after beginning of injection

\begin{tabular}{|c|c|c|c|c|c|c|c|c|c|c|c|c|}
\hline & \multicolumn{12}{|c|}{ Patient } \\
\hline & \multicolumn{2}{|c|}{ BP } & \multicolumn{2}{|c|}{ BB } & \multicolumn{2}{|c|}{ EM } & \multicolumn{2}{|c|}{$\mathrm{EH}$} & \multicolumn{2}{|c|}{ DN } & \multicolumn{2}{|c|}{ JA } \\
\hline Sex & \multicolumn{2}{|c|}{$\mathbf{F}$} & \multicolumn{2}{|c|}{$\mathbf{M}$} & \multicolumn{2}{|c|}{$\mathrm{F}$} & \multicolumn{2}{|r|}{$\mathbf{F}$} & \multicolumn{2}{|c|}{$\mathbf{F}$} & \multicolumn{2}{|c|}{$\mathbf{M}$} \\
\hline Age & \multicolumn{2}{|c|}{26} & \multicolumn{2}{|c|}{37} & \multicolumn{2}{|c|}{51} & & 37 & \multicolumn{2}{|c|}{47} & \multicolumn{2}{|c|}{58} \\
\hline \multicolumn{13}{|l|}{ Intravenous doses (mg) } \\
\hline Propranolol low & \multirow{4}{*}{\multicolumn{2}{|c|}{$\begin{array}{c}1 \cdot 25 \\
2 \cdot 5 \\
6 \cdot 0 \\
12 \cdot 0\end{array}$}} & \multicolumn{2}{|c|}{$1 \cdot 0$} & \multicolumn{2}{|c|}{$1 \cdot 0$} & & $1 \cdot 0$ & \multicolumn{2}{|c|}{0.5} & \multicolumn{2}{|c|}{$1 \cdot 0$} \\
\hline Propranolol high & & & \multirow{2}{*}{\multicolumn{2}{|c|}{$2 \cdot 0$}} & \multicolumn{2}{|c|}{$2 \cdot 0$} & & $2 \cdot 0$ & \multicolumn{2}{|c|}{1.0} & \multicolumn{2}{|c|}{$2 \cdot 0$} \\
\hline Ro 3-3528 low & & & $\begin{array}{r}6 \cdot 0 \\
12 \cdot 0\end{array}$ & & \multicolumn{2}{|c|}{$6 \cdot 0$} & & $6 \cdot 0$ & \multicolumn{2}{|c|}{$3 \cdot 0$} & \multicolumn{2}{|c|}{$6 \cdot 0$} \\
\hline Ro 3-3528 high & & & & .0 & & $2 \cdot 0$ & & $2 \cdot 0$ & & $6 \cdot 0$ & & $2 \cdot 0$ \\
\hline Plasma levels (ng/ml) & $\min a$ & fter injec & ion & & & & & & & & & \\
\hline Propranolol low & & $4 \cdot 4$ & & $\cdot 8$ & & $4 \cdot 4$ & & $3 \cdot 2$ & $<$ & & & $4 \cdot 9$ \\
\hline Propranolol high & & $1 \cdot 6$ & & $\cdot 9$ & & 0.5 & & $5 \cdot 4$ & & $3 \cdot 5$ & & $8 \cdot 6$ \\
\hline Ro 3-3528 low & & $4 \cdot 5$ & & $\cdot 1$ & & $8 \cdot 4$ & & $0 \cdot 0$ & & $5 \cdot 5$ & & $6 \cdot 8$ \\
\hline Ro 3-3528 high & & $4 \cdot 6$ & & $\cdot 5$ & & $7 \cdot 4$ & & $7 \cdot 0$ & & $\cdot 8$ & & $7 \cdot 2$ \\
\hline Ectopic beats* & & & & & & & & & & & & \\
\hline Saline & 0 & 0 & $3 \mathrm{~V}$ & $2 \mathrm{~V}$ & 0 & $3 S$ & 0 & 0 & 0 & 0 & $1 \mathrm{~V}$ & 0 \\
\hline Propranolol low & 0 & 0 & $2 \mathrm{~V}$ & 0 & 0 & $2 \mathrm{~S}$ & 0 & 0 & $1 \mathrm{~V}$ & $2 \mathrm{~V}$ & $1 \mathrm{~V}$ & 0 \\
\hline Propranolol high & $2 \mathrm{~V}$ & 0 & 0 & 0 & 0 & $2 S$ & 0 & 0 & 0 & 0 & 0 & 0 \\
\hline Ro 3-3528 low & 0 & $2 \mathrm{~V}$ & 0 & 0 & $\mathbf{0}$ & 0 & 0 & 0 & 0 & 0 & $1 \mathrm{~V}$ & 0 \\
\hline Ro 3-3528 high & 0 & $2 \mathrm{~V}, 1 \mathrm{~S}$ & 0 & 0 & 0 & 0 & 0 & 0 & $1 \mathrm{~V}$ & $1 \mathrm{~V}$ & $2 \mathrm{~V}$ & $1 \mathrm{~V}$ \\
\hline Relation to injection & Befor & e After & Befor & After & Before & After & Before & e After & Before & After & Before & After \\
\hline
\end{tabular}

$* \mathrm{~V}$, ventricular; $\mathrm{S}$, supraventricular.

$13 /$ min for subject DN) that, rather than double the doses on days 4 and 5 , the doses were halved.

At the start of each study, patients rested for $5 \mathrm{~min}$ on the bed. Heart rate was then recorded electrocardiographically every minute for $5 \mathrm{~min}$, following which an intravenous injection was given over $7.5 \mathrm{~min}$. Ectopic beats were noted and counted for $5 \mathrm{~min}$ before injection, during injection and for 10 min after injection. Heart rate was recorded every minute for $5 \mathrm{~min}$ after cessation of injection, and at 7.5 and $10 \mathrm{~min}$. Immediately after the last heart rate recording, $10 \mathrm{ml}$ of blood were obtained by venepuncture in the contralateral arm to the injection for estimation of plasma level of drug. Blood was collected in heparinized tubes, and plasma was separated by centrifugation at $3000 \mathrm{rpm}$ for $10 \mathrm{~min}$. Samples were deep-frozen and estimated up to 2 weeks after collection. No deterioration of fluorescence occurred in standard solutions kept under the same conditions for at least 8 weeks.

Estimation of propranolol was by the method first described by Black, Duncan \& Shanks (1965), and modified by Shand, Nuckolls \& Oates (1970).

Plasma levels of Ro 3-3528 were estimated fluorimetrically by the method of Long \& Francis (personal communication) and modified by Phillips \& Hicks (1972).

\section{Drugs}

Placebo used as normal saline.

Propranolol as the hydrochloride, 1 and $10 \mathrm{mg} / \mathrm{ml}$ (Inderal, ICI)
Ro 3-3528 (racemic 6,7-dimethyl- $\alpha$ [(isopropylamino) methyl] - 2 - benzofuranmethanol hydrochloride: synthesized by Dr Osbond, Roche Products Ltd) was used as $8 \mathrm{mg} / \mathrm{ml}$ solution in normal saline. All doses were diluted in normal saline to give a final volume of $2 \mathrm{ml}$.

\section{Results}

No patient experienced side-effects, but four volunteered on days in which they received active drugs that they noticed a suppression of palpitation for $2-4 \mathrm{hr}$ after injection. No patient noted improvement on saline days.

Ectopic supraventricular and ventricular beats were noted in five patients (Table 1). They occurred before and after injections of both $\beta$-adrenoceptorblocking agents and of saline. There was no evidence that either drug was associated with the production of dysrhythmias.

Pooled results from the six patients were submitted to analysis by Student's ' $t$ ' test. There was a significant difference between mean heart rates before and after injection of each drug in both doses $(P<0.001)$, whereas the change in mean heart rate on saline days was insignificant (Fig. 1 and Table 2). There was no significant difference between the drop in heart rates obtained after the low dose of propranolol and the low dose of Ro 3-3528; but a significant difference in changes in heart rate occurred between the high doses of both drugs $(P<0.02)$.

There was a highly significant difference between 


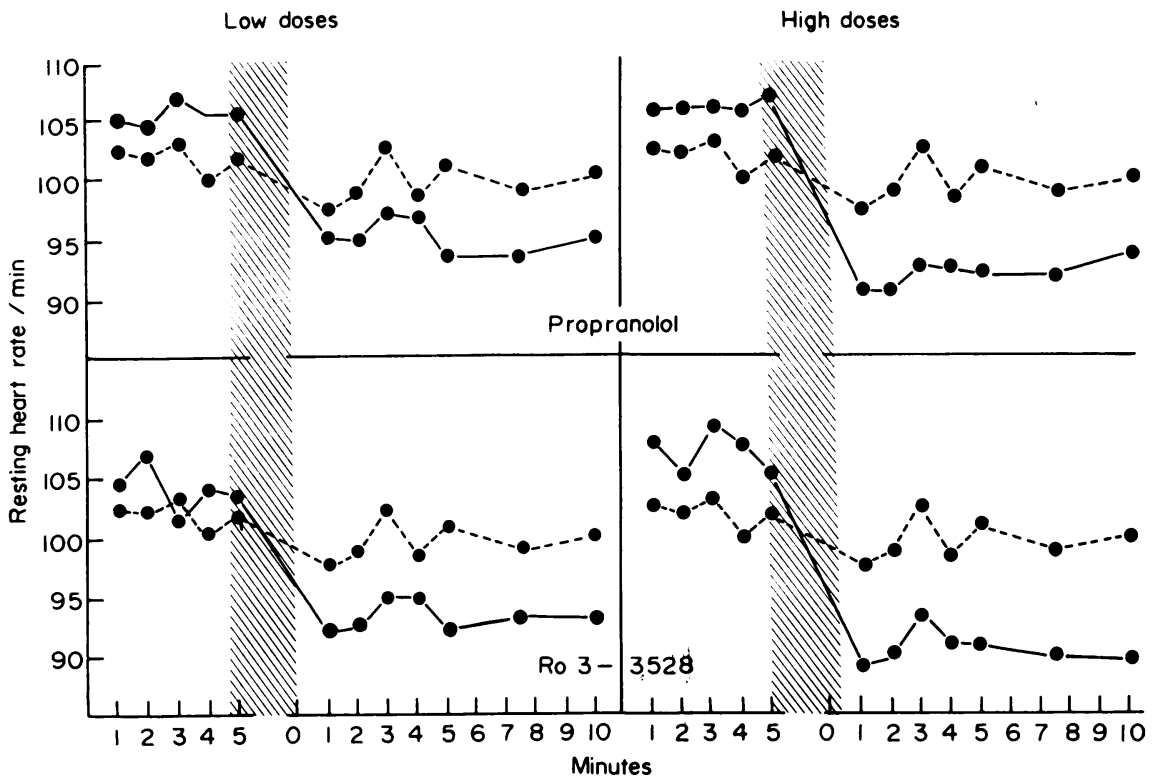

FIG. 1. Mean resting heart rates in six untreated hyperthyroid patients before and after intravenous saline (- - - ), or low or high doses of propranolol and Ro 3-3528 $(\longrightarrow)$. Diagonally hatched areas, injection over $7.5 \mathrm{~min}$.

TABLE 2. Mean resting heart rates in six hyperthyroid patients before and after intravenous injection of normal saline, propranolol or Ro 3-3528 in low and high doses

\begin{tabular}{|c|c|c|c|c|c|c|}
\hline Drug & $\begin{array}{c}\text { Number of } \\
\text { observations } \\
(n)\end{array}$ & $\begin{array}{l}\text { Mean } \\
\text { resting } \\
\text { heart } \\
\text { rate }\end{array}$ & SD & Variance & $t$ & $P$ \\
\hline Saline & & & & & & \\
\hline $\begin{array}{l}\text { Before injection } \\
\text { After injection }\end{array}$ & $\begin{array}{l}30 \\
40\end{array}$ & $\begin{array}{r}101 \cdot 7 \\
99 \cdot 5\end{array}$ & $\begin{array}{l}10 \cdot 5 \\
14 \cdot 60\end{array}$ & $\begin{array}{l}111 \cdot 3 \\
214 \cdot 7\end{array}$ & $2 \cdot 171$ & $<0.05$ \\
\hline $\begin{array}{l}\text { Propranolol } \\
\text { Low dose }\end{array}$ & & & & & & \\
\hline $\begin{array}{l}\text { Before injection } \\
\text { After injection }\end{array}$ & $\begin{array}{l}30 \\
40\end{array}$ & $\begin{array}{r}105 \cdot 6 \\
95 \cdot 0\end{array}$ & $\begin{array}{l}13 \cdot 50 \\
10 \cdot 40\end{array}$ & $\begin{array}{l}182 \cdot 4 \\
109 \cdot 1\end{array}$ & $11 \cdot 54$ & $<0.001$ \\
\hline $\begin{array}{l}\text { High dose } \\
\text { Before injection } \\
\text { After injection }\end{array}$ & $\begin{array}{l}30 \\
40\end{array}$ & $\begin{array}{r}106 \cdot 1 \\
92 \cdot 1\end{array}$ & $\begin{array}{l}11 \cdot 7 \\
11 \cdot 9\end{array}$ & $\begin{array}{l}137 \cdot 4 \\
142 \cdot 3\end{array}$ & $15 \cdot 25$ & $<0.001$ \\
\hline $\begin{array}{l}\text { Ro } 3-3528 \\
\text { Low dose }\end{array}$ & & & & & & \\
\hline $\begin{array}{l}\text { Before injection } \\
\text { After injection } \\
\text { High dose }\end{array}$ & $\begin{array}{l}30 \\
40\end{array}$ & $\begin{array}{r}104 \cdot 0 \\
93 \cdot 2\end{array}$ & $\begin{array}{l}12 \cdot 5 \\
11 \cdot 5\end{array}$ & $\begin{array}{l}157 \cdot 4 \\
133 \cdot 0\end{array}$ & $11 \cdot 63$ & $<0.001$ \\
\hline $\begin{array}{l}\text { Before injection } \\
\text { After injection }\end{array}$ & $\begin{array}{l}30 \\
40\end{array}$ & $\begin{array}{r}107 \cdot 1 \\
90 \cdot 6\end{array}$ & $\begin{array}{l}9 \cdot 5 \\
8 \cdot 2\end{array}$ & $\begin{array}{l}89 \cdot 9 \\
68 \cdot 4\end{array}$ & $24 \cdot 16$ & $<<0.001$ \\
\hline
\end{tabular}

Differences tested between pre-injection and postinjection heart rates using Student's ' $t$ ' test with 68 degrees of freedom. (Five observations were made on each of six patients before injection: seven observations were made on each of five patients, and five observations on the sixth patient after injection; the last observations being lost due to ECG failure.) 
the mean changes in heart rate following low and high doses of Ro 3-3528 $(P<0.001)$; the difference between mean heart rate changes after low and high doses of propranolol, although in the appropriate direction, did not rcach as high a level of significance ( $P \doteqdot 0.05$; Table 3, and Fig. 2).

Table 1 and Fig. 3 compare the plasma levels and effects of both drugs: a relationship is apparent between the mean log plasma level of both agents and their therapeutic effect.

\section{Discussion}

Ro 3-3528 and propranolol show a mean doseresponse effect on inhibition of hyperthyroid tachycardia, and this effect is related to the plasma level of the drug in each case. It is of interest that all six patients demonstrate a clear dose-response effect with Ro 3-3528: four out of the six show a similar response with propranolol, whereas two subjects (BP and EM, Table 1 and Fig. 2) showed less inhibition with the higher than with the lower dose of propranolol. Fitzgerald \& O'Donnell (1971) have shown in reserpinized animals that the active metabolite of propranolol, 4 - hydroxypropranolol, exhibits intrinsic sympathomimetic activity. However, the metabolite is not formed following intravenous injection, thus obviating this explanation for our anomalous results. If 4-hydroxypropranolol exerts intrinsic activity in man, such a factor might be important when considering treatment of hyperthyroid patients with oral propranolol, since its active metabolite would then be formed, countermanding to some extent the effect of the parent compound (Coltart \& Shand, 1970). Ro 3-3528 has no known active metabolites in man (Hornby,

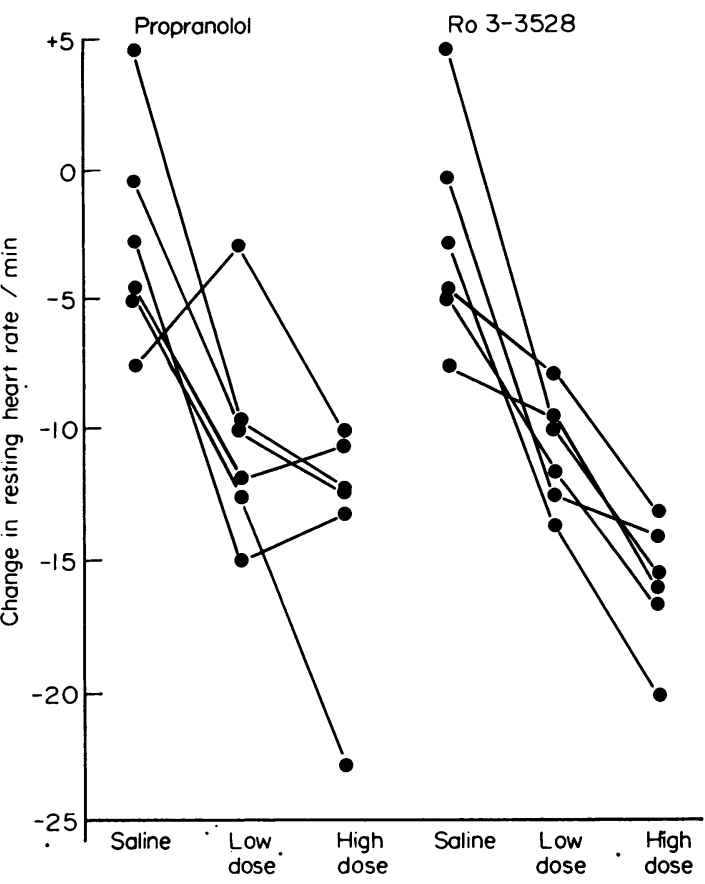

FIG. 2. Change in resting heart rate in six hyperthyroid patients following intravenous saline, propranolol or Ro 3-3528 in low or high doses.

(Heart rates are corrected to a common pre-injection rate for each subject).

1969). On this basis, it is possible that sotalol or Ro 3-3528 might be preferable to propranolol in the management of hyperthyroid states by oral therapy. We found that the intravenous administration

TABLE 3. Mean changes in heart rate in six hyperthyroid patients over $5 \mathrm{~min}$ following intravenous injection of normal saline, propranolol or Ro 3-3528 in low and high doses

\begin{tabular}{|c|c|c|c|c|c|c|}
\hline Drug & $\begin{array}{l}\text { Mean } \\
\text { change } \\
\text { in heart } \\
\text { rate }\end{array}$ & SD & Variance & $t$ & $P$ & \\
\hline \multirow{3}{*}{$\begin{array}{l}\text { Saline } \\
\text { Propranolol } \\
\text { Low dose } \\
\text { High dose } \\
\text { Ro 3-3528 } \\
\text { Low dose } \\
\text { High dose }\end{array}$} & $-2 \cdot 5$ & $6 \cdot 58$ & $43 \cdot 29$ & & & \multirow{3}{*}{$\begin{array}{l}\text { Mean drug response vs } \\
\text { mean saline response }\end{array}$} \\
\hline & $\begin{array}{l}-11 \cdot 3 \\
-14 \cdot 2\end{array}$ & $\begin{array}{l}5 \cdot 97 \\
5 \cdot 41\end{array}$ & $\begin{array}{l}35 \cdot 60 \\
29 \cdot 03\end{array}$ & $\begin{array}{l}5 \cdot 337 \\
7 \cdot 410\end{array}$ & $\left.\begin{array}{l}<0.001 \\
<0.001\end{array}\right\}$ & \\
\hline & $\begin{array}{l}-11 \cdot 5 \\
-17 \cdot 8\end{array}$ & $\begin{array}{l}4 \cdot 19 \\
4 \cdot 91\end{array}$ & $\begin{array}{l}17 \cdot 57 \\
24 \cdot 14\end{array}$ & $\begin{array}{r}6 \cdot 211 \\
10 \cdot 032\end{array}$ & $\begin{array}{l}<0.001 \\
<0.001\end{array}$ & \\
\hline \multirow{2}{*}{\multicolumn{2}{|c|}{$\begin{array}{l}\text { Low dose propranolol vs } \\
\text { high dose propranolol: } \\
\text { Low dose Ro 3-3528 vs } \\
\text { high dose Ro 3-3528: }\end{array}$}} & & & 1.942 & $\doteqdot 0.05$ & \multirow[t]{4}{*}{$\cdot$} \\
\hline & & & & $5 \cdot 254$ & $<0.001$ & \\
\hline \multirow{2}{*}{\multicolumn{2}{|c|}{$\begin{array}{l}\text { Low dose propranolol vs } \\
\text { low dose Ro } 3-3528 \text { : } \\
\text { High dose propranolol vs } \\
\text { high dose Ro } 3-3528 \text { : }\end{array}$}} & & & $0 \cdot 147$ & NS & \\
\hline & & & & $2 \cdot 659$ & $<0.02$ & \\
\hline
\end{tabular}




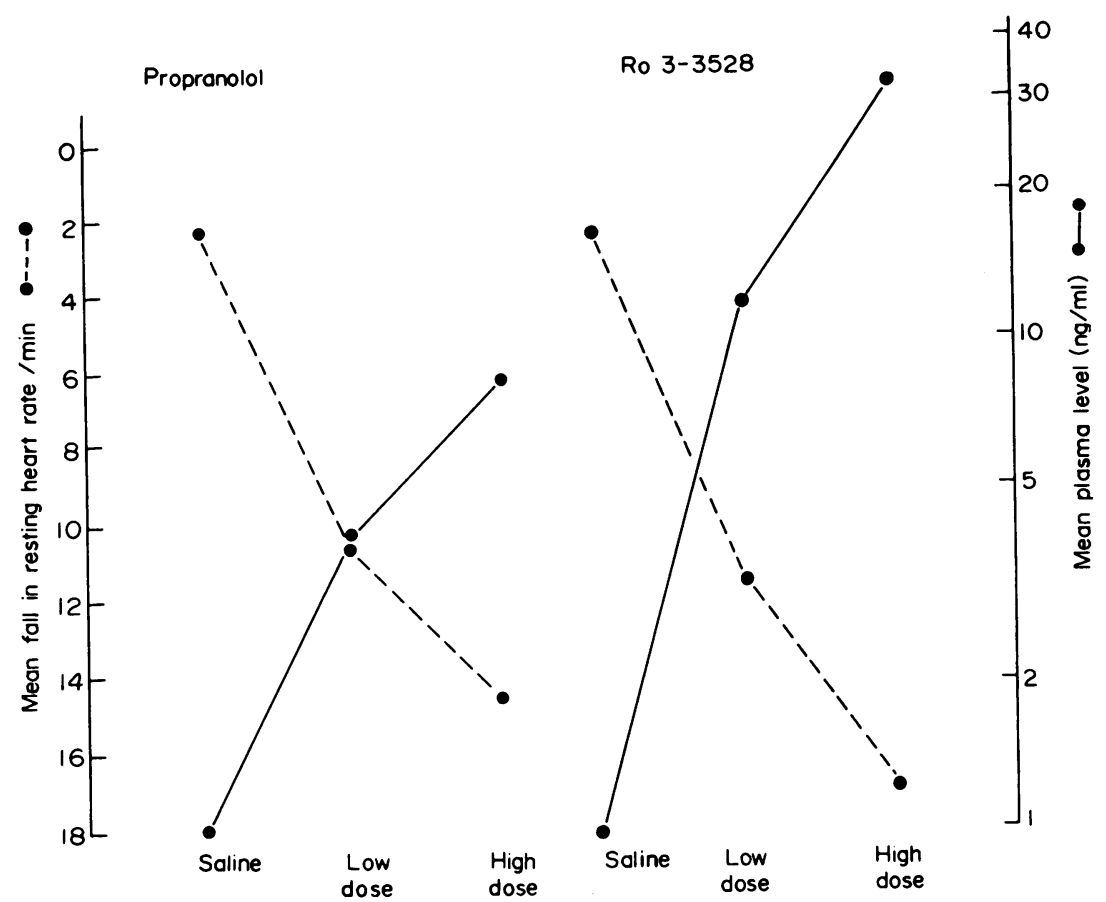

FIG. 3. Mean fall in resting heart rate (_- - ) and mean plasma levels of $\beta$-adrenoceptor blocker (- $\longrightarrow$ in six untreated hyperthyroid patients following intravenous saline, propranolol or Ro 3-3528 in low and high doses.

of neither propranolol nor Ro 3-3528 was associated with an increase in spontaneous ventricular or supraventricular ectopic beats; this would support our conclusion that $\beta$-adrenoceptor-blocking drugs without intrinsic activity have consistent inhibitory effects on hyperthyroid tachycardia without dysrhythmic effect, whereas those agents possessing intrinsic sympathomimetic activity do not predictably inhibit such a tachycardia, and may even be associated with the induction of arrhythmias. The cardioselective $\beta$-adrenolytic agent practolol, although perhaps preferred on the grounds of receptor selectivity, falls into the latter category.

\section{Acknowledgments}

It is a pleasure to thank the staff of St Bartholomew's Hospital and of the North Middlesex Hospital for their co-operation in this study, and Miss Deborah Hicks for the spectrophotofluorimetric estimations of drugs. E.M.P. is a Medical Research Council Clinical Research Fellow in Clinical Pharmacology.

We thank Roche Products for supplies of Ro 3-3528 and for financial support.

\section{References}

Arbab, A. G. \& Turner, P. (1971) Comprison of propranolol and LB 46 (prinodolol) on hyperthyroid tachycardia. Postgraduate Medical Journal, 47, 329.

Black, J.W., Duncan, W.A.M. \& Shanks, R.G. (1965) Comparison of some properties of pronethalol and propranolol. British Journal of Pharmacology, 25, 577.
Canary, J.J., SchaAf, M., Duffy, B.J. \& Kyle, L.H. (1957) Effects of oral and intramuscular administration of reserpine in thyrotoxicosis. New England Journal of Medicine, 257, 435.

Coltart, D.J. \& Shand, D.G. (1970) Plasma propranolol levels in the quantitative assessment of $\beta$-adrenergic blockade in man. British Medical Journal, 3, 731.

Ekue, J.M.K., Lowe, D.C. \& Shanks, R.G. (1970) Comparison of the effects of propranolol and MJ 1999 on cardiac $\beta$-adrenoceptors in man. British Journal of Pharmacology, 38, 546.

Fitzgerald, J.D. \& O'Donnell, Stella, R. (1971) Pharmacology of 4-hydroxypropranolol, a metabolite of propranolol. British Journal of Pharmacology, 43, 222.

Goldstein, S. \& Killip, T. (1965) Catecholamine depletion in thyrotoxicosis. Effect of guanethidine on cardiovascular dynamics. Circulation, 31, 219.

Haefely, W., Hurlimann, A. \& Thoenen, H. (1967) (6,7-dimethyl- $\alpha$ (isopropylamino) methyl-2-benzofuranulmethanol hydrochloride). Some pharmacological actions of the $\beta$-adrenolytic agent Ro 3-3528. Angiologica, 4, 203.

Hicks, Deborah C. \& Phillips, Eileen M. (1972) Preliminary studies of Ro 3-3528, a $\beta$-adrenoceptor blocking agent, in man. British Journal of Pharmacology, 44, 377P.

HORnBy, J. (1969) The biochemistry of drug action. Some experiments on metabolism of benzfuran compounds. M.Sc. Thesis, London.

Phillips, Eileen M. \& Hicks, Deborah C. (1972) Ro 3-3528, a $\beta$-adrenoceptor blocking agent: oral and intravenous pharmacokinetic studies in normal volunteers. To be published. 
Schneckloth, R.E., Kurland, G.S. \& Freedberg, A.S. (1953) Effect of variation in thyroid function on the pressor response to norepinephrine in man. Metabolism, 2, 546.

Shand, D.G., Nuckolls, E.M. \& OAtes, J.A. (1970) Plasma propranolol levels in adults with observations in four children. Clinical Pharmacology and Therapeutics, 11, 112.

TURNER, P. (1970) Alprenolol and propranolol in hyperthyroid tachycardia. British Journal of Pharmacology, 40, 46.
TURNER, P. \& Hill, R.C. (1968) A comparison of three $\boldsymbol{\beta}$-adrenergic receptor-blocking drugs in thyrotoxic tachycardia. Journal of Clinical Pharmacology, 8, 268.

Wilson, W.R., Theilen, E.O. \& Fletcher, F.W. (1964) Pharmacodynamic effects of $\beta$-adrenergic receptor blockade in patients with hperthyroidism. Journal of Clinical Investigation, 43, 1697. 